Article

\title{
Hierarchical Cs-Pollucite Nanozeolite Modified with Novel Organosilane as an Excellent Solid Base Catalyst for Claisen-Schmidt Condensation of Benzaldehyde and Acetophenone
}

\author{
Aleid Ghadah Mohammad S. 1,2 ${ }^{\text {, Fitri Khoerunnisa }}{ }^{3}$, Severinne Rigolet ${ }^{4,5}$, T. Jean Daou 4,5 (D, \\ Tau-Chuan Ling ${ }^{6}$ and Eng-Poh $\mathrm{Ng}^{1, *(D)}$ \\ 1 School of Chemical Sciences, Universiti Sains Malaysia, Penang 11800 USM, Malaysia; \\ mmss240@hotmail.com \\ 2 Department of Chemistry (Preparatory Year), Faculty of Science, University of Hail, P.O. Box 2440, \\ Hail 18451, Saudi Arabia \\ 3 Chemistry Education Department, Universitas Pendidikan Indonesia, Jl. Setiabudhi 258, Bandung 40514, \\ Indonesia; fitri.khoerunnisa@gmail.com \\ 4 Axe Matériaux à Porosités Contrôlées, Institut de Science de Matériaux de Mulhouse UMR 7361, Université \\ de Haute-Alsace, ENSCMu, 3b rue Alfred Werner, 68093 Mulhouse, France; severinne.rigolet@uha.fr (S.R.); \\ jean.daou@uha.fr (T.J.D.) \\ 5 Université de Strasbourg, 67000 Strasbourg, France \\ 6 Institute of Biological Sciences, Faculty of Science, University of Malaya, Kuala Lumpur 50603, Malaysia; \\ tcling@um.edu.my \\ * Correspondence: epng@usm.my; Tel.: +60-46533550
}

Received: 24 December 2019; Accepted: 9 January 2020; Published: 10 January 2020

\begin{abstract}
Cs-pollucite can be a potential solid base catalyst due to the presence of (Si-O-Al) ${ }^{-} \mathrm{Cs}^{+}$ basic sites. However, it severely suffers from molecular diffusion and pore accessibility problems due to its small micropore opening. Herein, we report the use of new organosilane, viz. dimethyloctadecyl[3-(trimethoxysilyl)propyl]ammonium chloride (TPOAC), as a promising pore-expanding agent to develop the hierarchical structure in nanosized Cs-pollucite. In respect to this, four different amounts of TPOAC were added during the synthesis of hierarchical Cs-pollucite $(\mathrm{CP}-x, x=0,0.3,1.0$, or 2.0, where $x$ is the molar ratio of TPOAC) in order to investigate the effects of TPOAC in the crystallization process of Cs-pollucite. The results show that an addition of TPOAC altered the physico-chemical and morphological properties of hierarchical Cs-pollucite, such as the crystallinity, crystallite size, pore size distribution, surface areas, pore volume, and surface basicity. The prepared solids were also tested in Claisen-Schmidt condensation of benzaldehyde and acetophenone, where $82.2 \%$ of the conversion and $100 \%$ selectivity to chalcone were achieved by the CP-2.0 catalyst using non-microwave instant heating $\left(200^{\circ} \mathrm{C}, 100 \mathrm{~min}\right)$. The hierarchical CP-2.0 nanocatalyst also showed better catalytic performance than other homogenous and heterogeneous catalysts and displayed a high catalyst reusability with no significant deterioration in the catalytic performance even after five consecutive reaction runs.
\end{abstract}

Keywords: Cs-pollucite; nanozeolite; hierarchical structure; organosilane porogen; Claisen-Schmidt condensation; non-microwave instant heating

\section{Introduction}

Zeolites are crystalline aluminosilicate microporous minerals and are considered widely used in many potential applications, such as adsorption, ion exchange, drug delivery, and catalysis [1-9]. 
In particular, Cs-pollucite is interesting because it has strong basic sites due to the presence of the alkali $\mathrm{Cs}^{+}$cation $[10,11]$. In addition, it has a three-dimensional open channel with an eight-membered ring pore size (pore opening $2.43 \AA$ ) forming a high thermally stable ANA framework structure [12]. However, the existence of small micropores in this zeolite provokes a barrier of diffusion limitation for guest molecules either from reactants or products [13]. In order to overcome the diffusion limitation of bulky molecules in Cs-pollucite, a viable approach has recently been proposed by downsizing the crystallite size to the nanometer range $(<100 \mathrm{~nm})$, with the aim of enhancing the external surface area of the zeolite [14-16]. As a result, the number of (Al-O-Si) ${ }^{-} \mathrm{Cs}^{+}$basic sites accessible for reactants is increased, giving considerably good catalytic activity in Perkin condensation of benzaldehyde [17] and cyanoethylation of amine [18]. However, the surface area of nanosized Cs-pollucite is still very low $\left(<40 \mathrm{~m}^{2} \mathrm{~g}^{-1}\right)$. Hence, any effort to improve the porous properties of Cs-pollucite zeolite with a more opened pore structure, better molecular diffusivity, and higher number of basic sites while maintaining its high thermal stability is urgently needed.

Pore-expanding agent, or so-called porogen, is an additive with a specified shape and size that can be used to create pores in an inorganic matrix, with the aim of increasing the accessibility of active sites, which leads to diffusion enhancement and catalytic activity. Typically, surfactants (e.g., cetyltrimethylammonium bromide, Tergitol 15-S-7), polymers (e.g., poly(ethylene glycol), poly(methyl methacrylate)), or macromolecules (e.g., sucrose, crown ether) have been added into synthesis precursors as porogens to produce inorganic materials with a hierarchical porous structure [19-23]. For instance, Zhu et al. successfully synthesized hierarchical zeolite beta using polyallyldimethylammonium cationic polymer (PDADMA) as both microporogen and mesoporogen [24]. The prepared zeolite exhibited improved catalytic activity and stability in the cracking reaction of triisopropylbenzene thanks to the enhanced pore diffusivity and surface acidity. In addition, hierarchical zeolite type $\mathrm{Y}$ was prepared using 1-methyl-3-[3'-(trimethoxysilyl)propyl]imidazolium chloride ionic liquid as a mesoporogen, and the resulting solid showed a distinct catalytic performance in the alkylation reaction due to its micro/mesoporous structural properties, which favored fast diffusion of the reactants and products [25]. Hence, this approach offers a promising alternative in enhancing the molecular diffusivity and catalytic activity by developing more open and porous structures.

Quaternary ammonium organosilanes are a promising porogen for the synthesis of hierarchical zeolites. Besides that, they can function as part of the silica source during the crystallization process. Typically, dimethylheptadecyl[3-(trimethoxysilyl)propyl]ammonium chloride (TPHAC) has been used to synthesize mesoporous zeolites (e.g., LTA, FAU) and (silico)aluminophosphates (e.g., AlPO-5, AlPO-11, and SAPO-5) materials [26-28]. However, the use of other organosilanes in the synthesis of hierarchical nanosized zeolite has not been widely reported [29]. In this paper, hierarchical nanosized Cs-pollucite zeolite was synthesized for the first time using dimethyloctadecyl[3-(trimethoxysilyl)propyl]ammonium chloride (TPOAC) organosilane as a new porogen, where different amounts of TPOAC were added into the precursor hydrogels. The effects of the eTPOAC contents on the physico-chemical properties, morphological features, and surface basicity of hierarchical Cs-pollucite nanocrystals were then studied. Furthermore, the catalytic behavior of the resulting solids in Claisen-Schmidt condensation of benzaldehyde and acetophenone was also investigated under non-microwave instant heating conditions.

\section{Experimental}

\subsection{Reproducible Synthesis of Hierarchically Structured Cs-Pollucite Nanocrystals}

The hierarchically structured Cs-pollucite zeolite (CP-x) was synthesized as follows: Initially, a clear aluminate solution was prepared by dissolving cesium hydroxide monohydrate $(10.500 \mathrm{~g}, 99.5 \%$, Sigma-Aldrich, Darmstadt, Germany), aluminum hydroxide (1.242 g, extra pure, Acros Organics, Geel, Belgium), and distilled water $(8.063 \mathrm{~g})$ at $105^{\circ} \mathrm{C}$ under stirring for $18 \mathrm{~h}$. The silicate solution was 
prepared by dissolving HS-40 (6.580 g, 40\% $\mathrm{SiO}_{2}$, Sigma-Aldrich, Darmstadt, Germany) and cesium hydroxide monohydrate $(5.550 \mathrm{~g})$ into distilled water $(6.400 \mathrm{~g})$. For the silicate solution, the required amount of dimethyloctadecyl[3-(trimethoxysilyl)propyl]ammonium chloride (TPOAC, 42\% methanol, Sigma-Aldrich, Darmstadt, Germany) was then added; for $x=0.3,1.0$, and 2.0, $2.800 \mathrm{~g}, 9.400 \mathrm{~g}$, and $18.800 \mathrm{~g}$ of TPOAC were added, respectively. Then, the aluminate solution was slowly mixed into to the resulting silicate solution under magnetic stirring $(450 \mathrm{rpm})$. A clear precursor suspension with a chemical composition of $5.5 \mathrm{SiO}_{2}: 1 \mathrm{Al}_{2} \mathrm{O}_{3}: 6 \mathrm{Cs}_{2} \mathrm{O}: 140 \mathrm{H}_{2} \mathrm{O}: x \mathrm{TPOAC}$ was then formed, where $x$ is the molar ratio of TPOAC organosilane in respect to $\mathrm{Al}_{2} \mathrm{O}_{3}$. The resulting precursor mixture was transferred to an autoclave and crystallized at $180^{\circ} \mathrm{C}$ for $2 \mathrm{~h}$. The white solid product was washed with distilled water via high speed centrifugation $(10,000 \mathrm{rpm}, 8 \mathrm{~min})$ until $\mathrm{pH} 7$. The colloidal suspension was freeze-dried and calcined at $750{ }^{\circ} \mathrm{C}$ for $6 \mathrm{~h}$ with a heating rate of $2^{\circ} \mathrm{C} \mathrm{min}-1$, where it took $6 \mathrm{~h}$ to reach the calcination temperature. The obtained powder samples were finally labelled as CP- $x(x=0$, $0.3,1.0$, or 2.0 molar ratio of TPOAC).

\subsection{Characterization}

The crystalline phase of the solid samples was analyzed using a PANalytical X'Pert PRO XRD diffractometer with $\mathrm{Cu}-\mathrm{K} \alpha$ radiation $(\lambda=1.5406 \AA)$. The samples were scanned with a step size of $0.02^{\circ} \mathrm{min}^{-1}$ from $2 \theta=3-50^{\circ}$. The crystallite size of the zeolite solids was estimated by using the Scherrer equation. The morphological characteristics of amorphous particles were studied by using a Philips XL-30 field emission scanning electron microscope (FESEM) operating at $20 \mathrm{kV}$. The particle size of the samples was measured using ImageJ software by randomly counting 100 particles through FESEM images obtained in different areas. The porosity of samples was determined using a Micromeritics ASAP 2010 nitrogen adsorption analyzer. The samples were first degassed at $250{ }^{\circ} \mathrm{C}$ overnight under vacuum conditions before being adsorbed with nitrogen probe molecules. The organic and inorganic compositions of samples were determined using a Mettler TGA SDTA851 instrument with a heating rate of $20^{\circ} \mathrm{C} \mathrm{min}{ }^{-1}$ from 30 to $900{ }^{\circ} \mathrm{C}$ in $\mathrm{N}_{2}$ atmosphere with a purge rate of $20 \mathrm{~mL} / \mathrm{min}$. The infrared (IR) spectra of the solids were recorded with a Perkin Elmer's System 2000 spectrometer using the $\mathrm{KBr}$ pellet technique (KBr:sample ratio = 50:1). The chemical composition of samples was obtained by using a Varian Vista MPX ICP-OES spectrometer, where the solid powder was first dissolved in hydrofluoric acid solution $(0.5 \mathrm{M}) . \mathrm{H}_{3} \mathrm{BO}_{3}$ was also added into the prepared solution to minimize fluoride interference during elemental analysis. The ${ }^{29} \mathrm{Si}$ MAS nmR spectroscopy analysis was performed using a Bruker Avance II $400 \mathrm{MHz}$ spectrometer (9.4 Tesla). Prior to analysis, the sample powder was packed into a $4-\mathrm{mm} \mathrm{ZrO}_{2}$ rotor and spun at $12 \mathrm{kHz}$. The chemical shifts were referred to tetramethylsilane (TMS). A single pulse excitation was applied with a $\pi / 6$ length of $2.1 \mu$ and a recycle delay of $80 \mathrm{~s}$, and the spectra were measured by the accumulation of 2000 scans. The detection and measurement of the strength of basic sites was investigated using the temperature-programmed desorption of carbon dioxide ( $\mathrm{CO}_{2}$-TPD). The analysis was performed on a BELCAT-B instrument, where the sample (ca. $80 \mathrm{mg}$ ) was first degassed at $400{ }^{\circ} \mathrm{C}$ overnight. The sample was then adsorbed with $\mathrm{CO}_{2}$ gas before the gas was slowly desorbed in the temperature range of 40 to $800{ }^{\circ} \mathrm{C}$ using a heating rate of $10^{\circ} \mathrm{C} / \mathrm{min}$.

\subsection{Catalytic Claisen-Schmidt Condensation Reaction Study}

Activated CP- $x$ catalyst (0.500 g), benzaldehyde (10 mmol, 99\%, Merck, Darmstadt, Germany), and acetophenone ( $5 \mathrm{mmol}, 99 \%$, Sigma-Aldrich) were added into a $10-\mathrm{mL}$ quartz reaction vessel, sealed with a silicone cap, and heated at a desired temperature (180-200 ${ }^{\circ} \mathrm{C}$ ) for $100 \mathrm{~min}$ by using an Anton Paar's Monowave 50 non-microwave instant heating reactor. The reaction solution was isolated and analyzed with a GC-FID chromatograph (Agilent/HP6890 GC, HP-5 capillary column, Santa Clara, CA, USA) and the identity of the reaction product was confirmed by a GC-MS (Agilent 7000 Series Triple Quad, Santa Clara, CA, USA). 


\subsection{Catalyst Reusability Study}

The zeolite catalyst after the first run of catalytic reaction was isolated, washed with diethyl ether $(15 \mathrm{~mL}) 5$ times, and air dried. The solid catalyst was re-activated $\left(300^{\circ} \mathrm{C}, 3 \mathrm{~h}\right)$ before being used for the subsequent runs of catalytic reaction. After the reaction, the reaction product was separated again and analyzed using GC-FID.

\section{Results and Discussion}

\subsection{Synthesis and Characterization of Hierarchical Cs-Pollucite Nanozeolites}

The as-synthesized CP- $x$ samples $(x=0,0.3,1.0$, and 2.0) were first subjected to thermogravimetry analysis in order to confirm the amount of TPOAC incorporated into the Cs-pollucite. For CP-0, only one-step weight loss was shown from 30 to $295^{\circ} \mathrm{C}$ due to the desorption of water (Figure 1a). As shown, the weight loss was very small $(0.64 \%)$ because the water can only be adsorbed on the external surface of CP-0 while water molecules are too big to access the micropores of Cs-pollucite [17]. When TPOAC was added, additional weight losses were detected from 228 to $765^{\circ} \mathrm{C}$ (Figure $1 \mathrm{~b}-\mathrm{d}$ ). As shown, the weight loss in these steps increases with the amount of TPOAC introduced. For CP-0.3, there was a $1.72 \%$ weight loss, increasing to $4.43 \%$ and $5.98 \%$ for CP-1.0 and CP-2.0, respectively. In addition, an interesting fact is also observed where TPOAC can only be entirely desorbed from CP-0.3, CP-1.0, and CP-2.0 at very high temperature $\left(>700^{\circ} \mathrm{C}\right)$ due to the TPOAC molecular inclusion in the small pores of Cs-pollucite and the formation of covalent bonds between TPOAC and the zeolitic framework via the condensation reaction of methoxy groups of TPOAC and the silanol groups of Cs-pollucite zeolite [30].

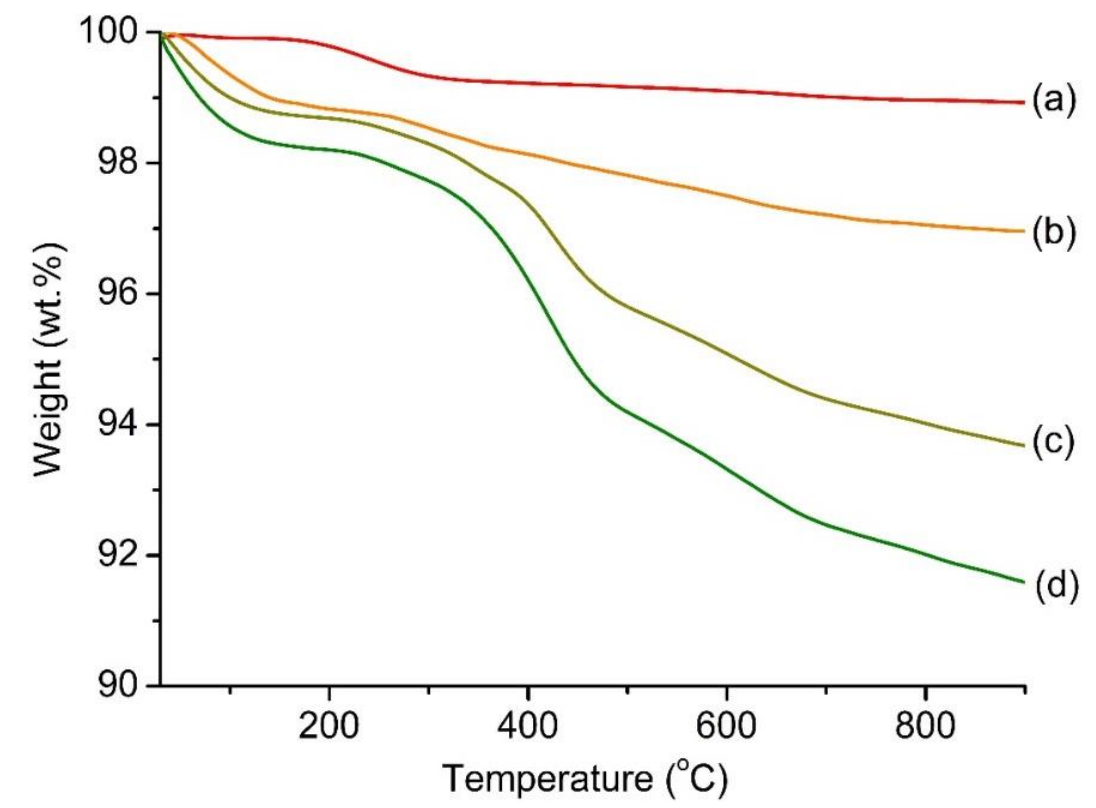

Figure 1. TG curves of as-synthesized (a) CP-0, (b) CP-0.3, (c) CP-1.0, and (d) CP-2.0.

In order to confirm that TPOAC was chemically bound to the Cs-pollucite framework, as-synthesized CP-0 and CP-2.0 were selected and characterized with ${ }^{29} \mathrm{Si} \mathrm{MAS} \mathrm{+} \mathrm{DEC} \mathrm{nmR} \mathrm{spectroscopy.}$ For CP-0, a broad signal is shown in the range of -72.9 to $-104.1 \mathrm{ppm}$, where this band is due to the $\mathrm{Q}_{1}$ : $\mathrm{Si}(\mathrm{OAl})_{4}$ and $\left.\mathrm{Q}_{2}: \mathrm{Si}(\mathrm{OSi})(\mathrm{OAl})_{3}\right)$ species originating from the Cs-pollucite framework (Figure 2a) [18]. On the other hand, CP-2.0 also exhibits the same nmR band at this region and a weak additional broad peak is also observed from -55 to $-75 \mathrm{ppm}$, where this peak is contributed by the $T_{n}$ species $\left(\mathrm{T}_{\mathrm{n}}=\mathrm{RSi}(\mathrm{OH})_{3-n}, \mathrm{n}=2\right.$ and 3$)$ of TPOAC (Figure 2b) [31]. Thus, it demonstrates that the TPOAC organosiloxane was chemically connected to the Cs-pollucite framework. 


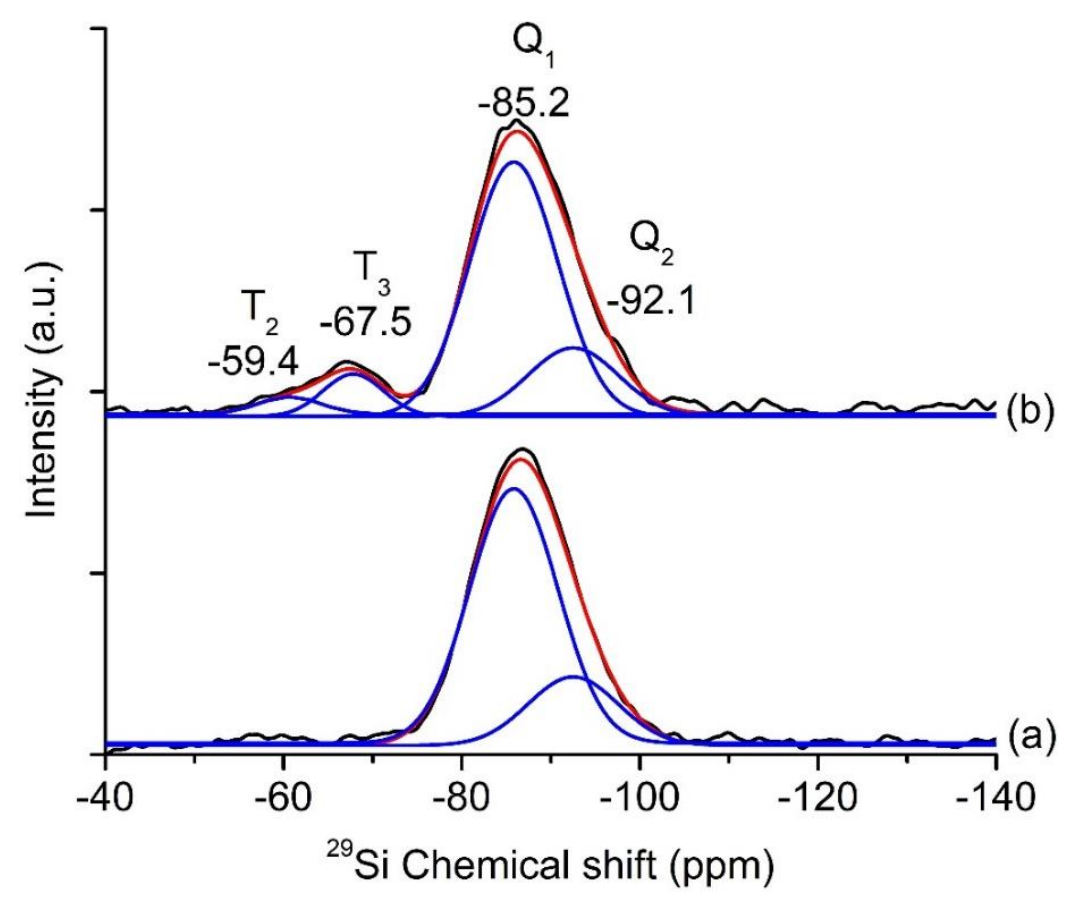

Figure 2. ${ }^{29} \mathrm{Si}$ MAS + DEC nmR spectra of as-synthesized (a) CP-0 and (b) CP-2.0.

The as-synthesized CP-0, CP-0.3, CP-1.0, and CP-2.0 were calcined and the XRD patterns of the respective samples are shown in Figure 3. It can be seen that all calcined samples display XRD patterns similar to that reported in the literature (JCPDS card no. 29-0407), revealing that Cs-pollucite with an ANA framework structure was obtained [32]. In addition, the XRD peaks' intensity (e.g., the [321], [400], and [332] peaks) of the samples decreased when more TPOAC was used, thus indicating that the addition of TPOAC interrupted the crystallization process of Cs-pollucite. The XRD peaks of the samples (e.g., [321], [400], [332], and [440] peaks) also broadened when TPOAC was added. Such a phenomenon can be explained by the reduced crystallite size [33]. The crystallite size of Cs-pollucite samples was calculated using the Scherrer equation. It is shown that CP-0 has a crystallite size of $66.94 \mathrm{~nm}$ and the size decreases to 55.20 (CP-0.3), 33.37 (CP-1.0), and $31.57 \mathrm{~nm}(\mathrm{CP}-2.0)$.

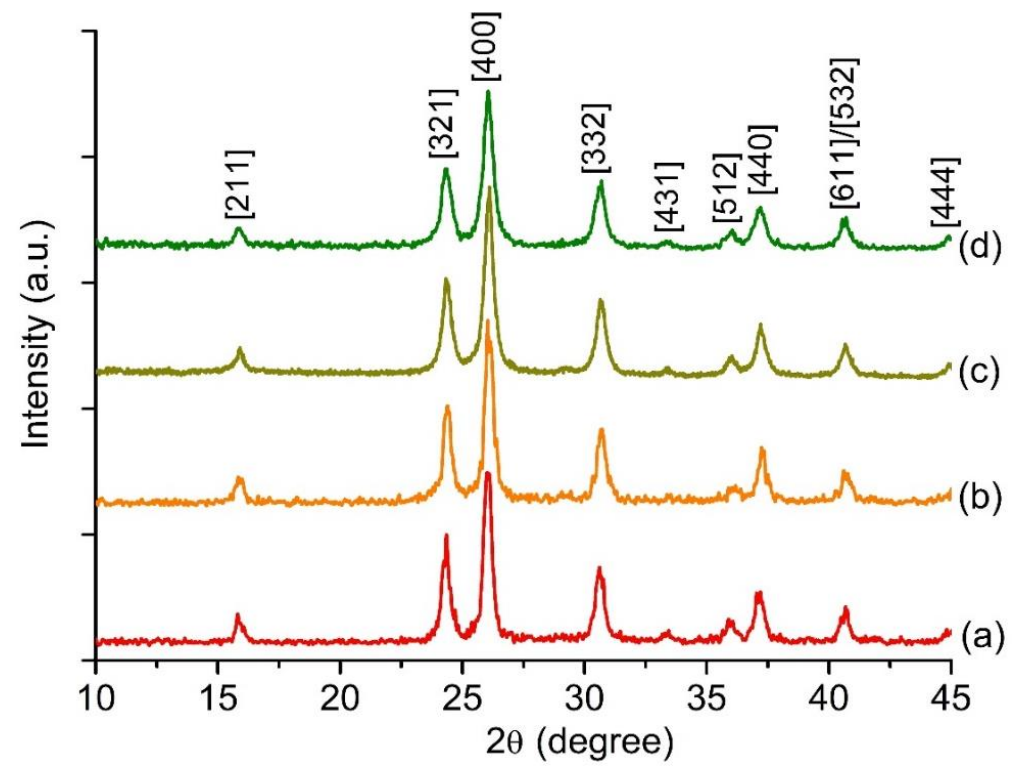

Figure 3. XRD patterns of calcined (a) CP-0, (b) CP-0.3, (c) CP-1.0, and (d) CP-2.0. 
The Cs-pollucite samples were also studied with an FESEM instrument. As seen, all samples consisted of discrete, uniform, and very fine particles (Figure 4). The particle size distribution of the samples was plotted based on 100 crystals randomly chosen from different FESEM imaging spots. In general, all samples exhibited a monomodal particle size distribution. For CP-0, the crystals were sized from 66.9 to $93.2 \mathrm{~nm}$ centered at $79.6 \mathrm{~nm}$. When more TPOAC was added, the size distribution became narrower and the average crystal size also decreased, indicating that TPOAC plays a role in controlling the crystallite size. For instance, CP-0.3 had a crystal size ranging from 56.5 to $83.3 \mathrm{~nm}$, with an average size of $69.8 \mathrm{~nm}$. The size distribution decreased to 15.3 to $33.1 \mathrm{~nm}$ for CP-2.0, centered at $23.3 \mathrm{~nm}$. Thus, the FESEM microscopy analysis results are fully in line with the XRD observation.
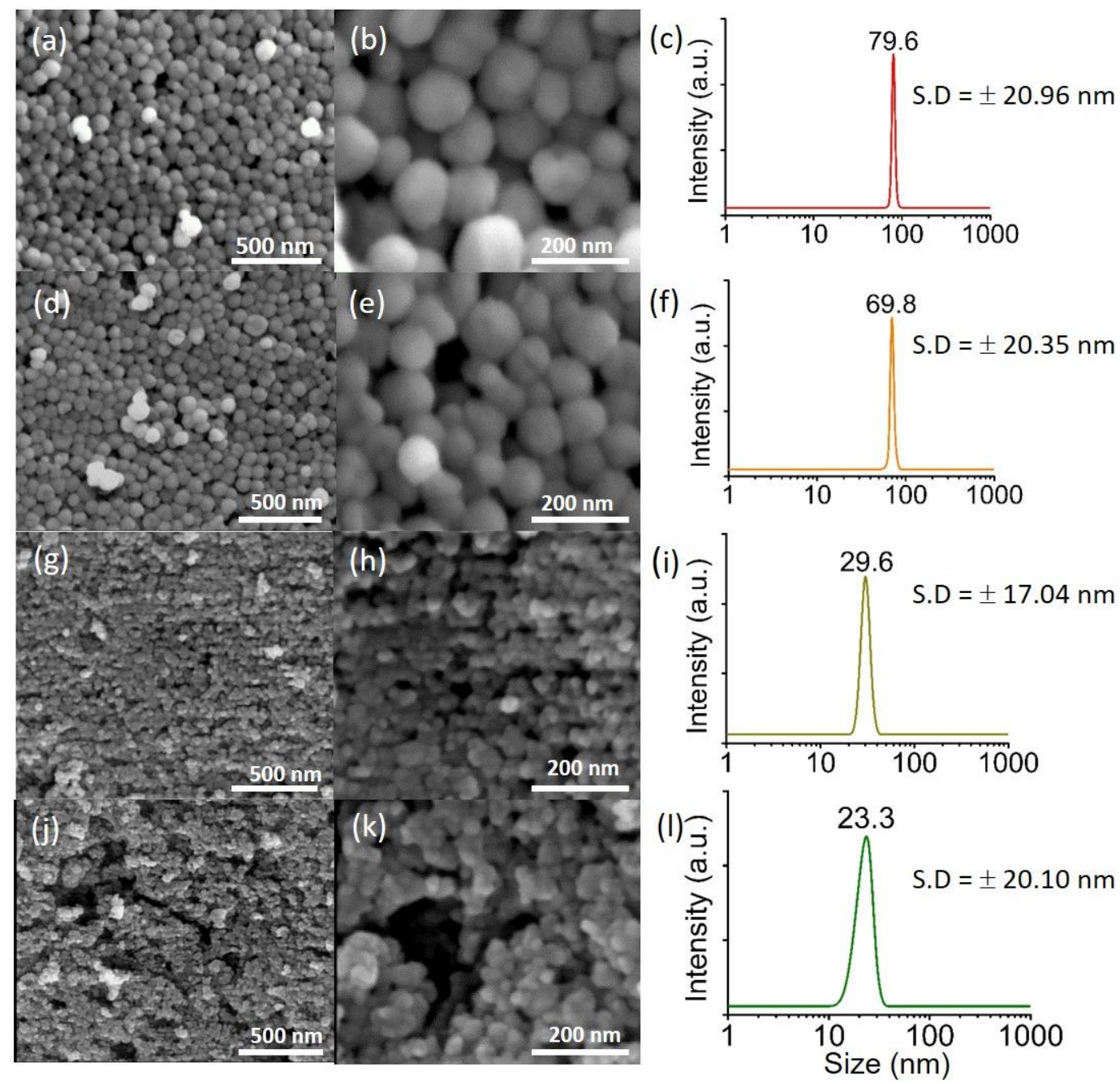

Figure 4. FESEM and particle size distributions (with standard deviation, S.D) of calcined (a-c) CP-0, (d-f) CP-0.3, (g-i) CP-1.0, and (j-1) CP-2.0.

IR spectroscopy was used to study the framework stability of CP- $x$ samples by examining their functional groups. In general, all samples displayed almost similar IR spectrum patterns as that of the theoretical pollucite solid, indicating that all samples retained their framework identity as also previously confirmed by the XRD study (Figure 5). The IR bands at 1014 and $1035 \mathrm{~cm}^{-1}$ are assigned to the internal vibrations of $\mathrm{Si}-\mathrm{O}-\mathrm{T}(\mathrm{T}=\mathrm{Si}, \mathrm{Al})$ asymmetric stretching modes while the signals resonated at 774,720 , and $631 \mathrm{~cm}^{-1}$ are the characteristics of distorted eight-membered ring sub-units present in the pollucite framework [18]. Furthermore, the IR band at $441 \mathrm{~cm}^{-1}$ is due to the bending vibration of $\mathrm{TO}_{4}$. On the other hand, two signals detected at 3458 and $1646 \mathrm{~cm}^{-1}$ are assigned to the stretching and bending vibrations of $\mathrm{O}-\mathrm{H}$ groups of water, respectively [34]. As can be seen, the $\mathrm{O}-\mathrm{H}$ bands become 
more intense with an increasing TPOAC concentration, indicating the hydrophilicity enhancement of the zeolites.

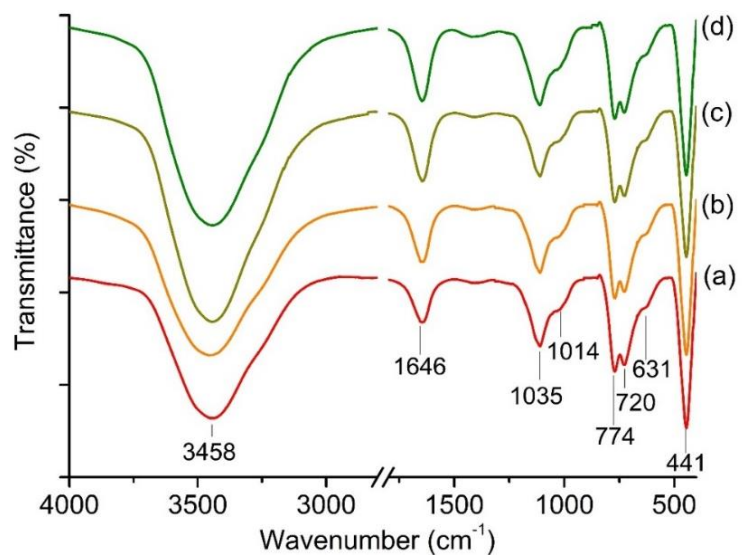

Figure 5. IR spectra of calcined (a) CP-0, (b) CP-0.3, (c) CP-1.0, and (d) CP-2.0.

The roles of TPOAC on the porous properties of Cs-pollucite nanozeolites were investigated with nitrogen adsorption-desorption isotherm analysis. CP-0 exhibited a type $\mathrm{V}$ adsorption isotherm with an $\mathrm{H} 1$ hysteresis loop (Figure 6a). Thus, it reveals the presence of cylindrical mesopores with a mean pore size distribution of ca. $35.0 \mathrm{~nm}$ (total average pore size is $31.7 \mathrm{~nm}$ ) originating from the close packing of nanocrystals [35]. Neither the microporosity nor micropore volume were detected due to the smaller pore size of pollucite zeolite $(\sigma=2.43 \AA)$ than the nitrogen molecular size $(\sigma=$ $3.64 \AA$ A $)[12,36]$. As a result, only a fairly low external surface area $\left(38 \mathrm{~m}^{2} / \mathrm{g}\right)$ and moderate total pore volume $\left(0.29 \mathrm{~cm}^{3} \mathrm{~g}^{-1}\right)$ were measured (Table 1$)$. The adsorption isotherm slowly changed from type $\mathrm{V}$ to type IV when an increasing amount of $\mathrm{N}_{2}$ uptake was observed at low $\mathrm{P} / \mathrm{P}_{\mathrm{o}}$ when more amount of TPOAC was added, indicating the development of hierarchical porosities (Figure $6 \mathrm{~b}-\mathrm{d}$ ). This phenomenon is also supported by the pore size distribution analysis determined using the DFT method, where secondary porosities consisted of micro- and macroporosities were detected in CP-0.3, CP-1.0, and CP-2.0, with CP-2.0 having the largest accessible porosities (largest pore sizes) (inset of Figure 6). In addition, a significant increase in the $\mathrm{S}_{\mathrm{BET}}$ (contributed by both the micropore and external surface areas) and $\mathrm{V}_{\text {Total }}$ was also observed, particularly for CP-2.0 ( $\mathrm{S}_{\mathrm{BET}}=152 \mathrm{~m}^{2} \mathrm{~g}^{-1}, \mathrm{~V}_{\text {Total }}$ $\left.=0.63 \mathrm{~cm}^{3} \mathrm{~g}^{-1}\right)$, thanks to the function of TPOAC as porogen, where the large amount of TPOAC added tended to form more micelles, which created micro- and macroporosities to the Cs-pollucite zeolites (Table 1) [37].

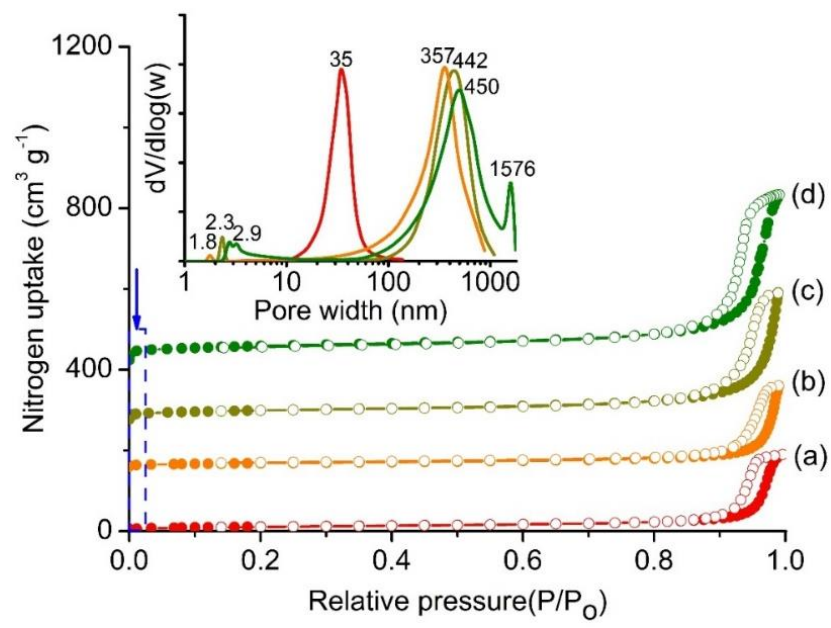

Figure 6. Nitrogen gas adsorption (closed symbols) and desorption (open symbols) curves of (a) CP-0, (b) CP-0.3, (c) CP-1.0, and (d) CP-2.0. Inset: Pore size distribution derived from the DFT method. 
Table 1. Textural properties of the Cs-pollucite zeolites synthesized with different TPOAC contents ${ }^{\text {a }}$.

\begin{tabular}{cccccc}
\hline Sample & $\mathbf{S}_{\text {BET }}\left(\mathbf{m}^{\mathbf{2}} \mathbf{g}^{-\mathbf{1}}\right)$ & $\mathbf{S}_{\text {ext }}\left(\mathbf{m}^{\mathbf{2}} \mathbf{g}^{\mathbf{- 1}}\right)$ & $\mathbf{S}_{\text {micro }}\left(\mathbf{m}^{\mathbf{2}} \mathbf{g}^{-\mathbf{1}}\right)$ & $\mathbf{V}_{\text {micro }}\left(\mathbf{c m}^{\mathbf{3}} \mathbf{g}^{-\mathbf{1}}\right)$ & $\mathbf{V}_{\text {total }}\left(\mathbf{c m}^{\mathbf{3}} \mathbf{g}^{-\mathbf{1}}\right)$ \\
\hline CP-0 & 38 & 38 & 0 & 0 & 0.29 \\
CP-0.3 & 62 & 59 & 3 & 0.002 & 0.30 \\
CP-1.0 & 108 & 71 & 37 & 0.011 & 0.49 \\
CP-2.0 & 152 & 89 & 63 & 0.019 & 0.63 \\
\hline
\end{tabular}

${ }^{\text {a }} S_{\text {BET }}$ : Specific surface area; $S_{\text {ext }}$ : External surface area; $S_{\text {micro }}$ : Micropore surface area; $V_{\text {micro }}$ : Micropore volume; $\mathrm{V}_{\text {total }}$ : Total pore volume.

The effects of TPOAC on the framework composition of Cs-pollucite zeolites were also investigated using ICP-OES spectroscopy analysis. In general, the Si/Al ratios of all samples are ca. 2.10 while the $\mathrm{Cs} / \mathrm{Al}$ ratios are close to unity, indicating that TPOAC exhibits no influence on the $\mathrm{Si}, \mathrm{Al}$, and $\mathrm{Cs}$ elemental distributions in the framework structure of Cs-pollucite zeolites (Table 2).

Table 2. Chemical elemental analysis of the solid products obtained after various heating times.

\begin{tabular}{ccccccccc}
\hline \multirow{2}{*}{ Sample } & \multicolumn{2}{c}{$\mathbf{S i}$} & \multicolumn{2}{c}{$\mathbf{A l}$} & \multicolumn{2}{c}{ Cs } & \multirow{2}{*}{ Si/Al Ratio } & \multirow{2}{*}{ Cs/Al Ratio } \\
\cline { 2 - 6 } & mg L $^{\mathbf{- 1}}$ & $\mathbf{m m o l ~ L}^{\mathbf{- 1}}$ & $\mathbf{m g ~ L}^{\mathbf{- 1}}$ & $\mathbf{m m o l ~ L}^{\mathbf{- 1}}$ & $\mathbf{m g ~ L}^{\mathbf{- 1}}$ & $\mathbf{m m o l ~ L}^{\mathbf{- 1}}$ & & \\
\hline CP-0 & 113.18 & 4.03 & 51.26 & 1.90 & 265.82 & 2.00 & 2.12 & 1.05 \\
CP-0.3 & 107.65 & 3.83 & 49.10 & 1.82 & 241.89 & 1.82 & 2.10 & 1.00 \\
CP-1.0 & 91.81 & 3.66 & 47.21 & 1.75 & 235.25 & 1.77 & 2.09 & 1.01 \\
CP-2.0 & 88.46 & 3.51 & 44.79 & 1.66 & 221.95 & 1.67 & 2.11 & 1.00 \\
\hline
\end{tabular}

The surface basicity of Cs-pollucite samples was investigated with $\mathrm{CO}_{2}-\mathrm{TPD}$ analysis, where this analysis can accurately determine the distribution of basic strengths of a solid catalyst [38]. It was shown that $\mathrm{CP}-0$ has the lowest number of basic sites $\left(58.7 \mu \mathrm{mol} \mathrm{g}^{-1}\right)$, where they are mostly contributed by the weak-to-mild basic sites ( $33.3 \mu \mathrm{mol} \mathrm{g}^{-1}, 56.7 \%$ ) (Figure 7a, Table 3). With the introduction of TPOAC into the hydrogel precursor of Cs-pollucite, the basicity (both in quantity and strength) increased thanks to the role of TPOAC as a porogen that develops more accessible porosities (Figure $7 \mathrm{~b}-\mathrm{d}$ ). As can be seen, the total number of basic sites increased from 58.7 (CP-0) to $64.7(\mathrm{CP}-0.3)$ and $69.4 \mu \mathrm{mol} \mathrm{g}{ }^{-1}$ (CP-1.0) before it further increased to $77.9 \mu \mathrm{mol} \mathrm{g}^{-1}$ (CP-2.0). Among the samples prepared, the basic strength of the solids follows this order: CP-2.0 > CP-1.0 > CP-0.3 > CP-0, where CP-2.0 has the largest number of mild-to-strong basic sites $\left(27.3 \mu \mathrm{mol} \mathrm{g}{ }^{-1}\right)$.

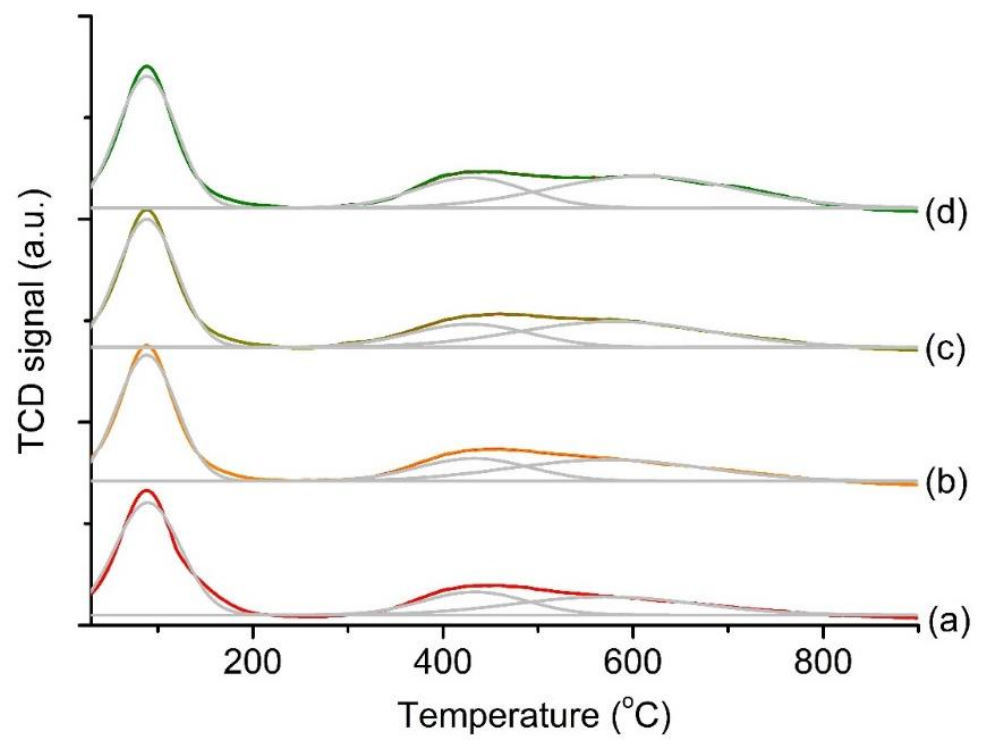

Figure 7. $\mathrm{CO}_{2}-\mathrm{TPD}$ of (a) $\mathrm{CP}-0,(\mathbf{b}) \mathrm{CP}-0.3$, (c) $\mathrm{CP}-1.0$, and (d) $\mathrm{CP}-2.0$. 
Table 3. Surface basicity of CP- $x$ Cs-pollucite zeolite samples determined using $\mathrm{CO}_{2}-\mathrm{TPD}$ analysis.

\begin{tabular}{|c|c|c|c|c|}
\hline \multirow{2}{*}{ Samples } & \multicolumn{4}{|c|}{ 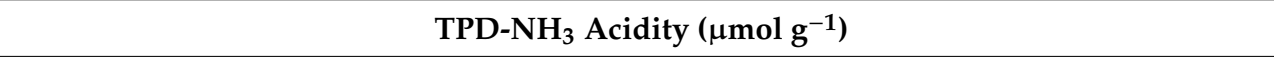 } \\
\hline & Weak-To-Mild $\left(30-200{ }^{\circ} \mathrm{C}\right)$ & Mild $\left(295-562{ }^{\circ} \mathrm{C}\right)$ & Mild-To-Strong $\left(390-800{ }^{\circ} \mathrm{C}\right)$ & Total \\
\hline $\mathrm{CP}-0$ & 33.3 & 11.0 & 14.4 & 58.7 \\
\hline CP-0.3 & 33.7 & 11.7 & 19.3 & 64.7 \\
\hline CP-1.0 & 34.4 & 12.4 & 22.6 & 69.4 \\
\hline CP-2.0 & 35.4 & 15.2 & 27.3 & 77.9 \\
\hline
\end{tabular}

An attempt to correlate the surface basicity with the amount of TPOAC added and $\mathrm{S}_{\mathrm{BET}}$ was also made. Figure 8 shows the correlation plots between $\mathrm{S}_{\mathrm{BET}}$, amount of TPOAC added, and the basicity of the Cs-pollucite samples. As shown, the basicity has a positive relationship with the TPOAC added, where the correlation is best described with a linear line, $y=8.99 x+60.26$, with the best of fit, $\mathrm{R}^{2}=$ 0.9715. In addition, the $S_{\text {BET }}$ was also found to have direct influence on the basicity of the Cs-pollucite samples, where the relation can be described with a linear equation: $y=56.43 x+43.44$, where $R^{2}=$ 0.9847. For CP-0, which has the lowest $\mathrm{S}_{\mathrm{BET}}\left(38 \mathrm{~m}^{2} \mathrm{~g}^{-1}\right)$, the basicity was found to be $58.7 \mu \mathrm{mol} \mathrm{g} \mathrm{g}^{-1}$. The basicity increased to 64.7 (CP-0.3), 69.4 (CP-1.0), and $77.9 \mu \mathrm{mol} \mathrm{g}^{-1}$ (CP-2.0) when the $\mathrm{S}_{\mathrm{BET}}$ of the solids increased. Thus, the results show that an addition of TPOAC in the synthesis of hierarchical Cs-pollucite is essential as it enhances the accessible surface area and surface basicity, where the basicity (number of basic sites) of Cs-pollucite, namely (Si-O-Al) ${ }^{-} \mathrm{Cs}^{+}$, is strongly associated with the total accessible surface area of the solids [39].

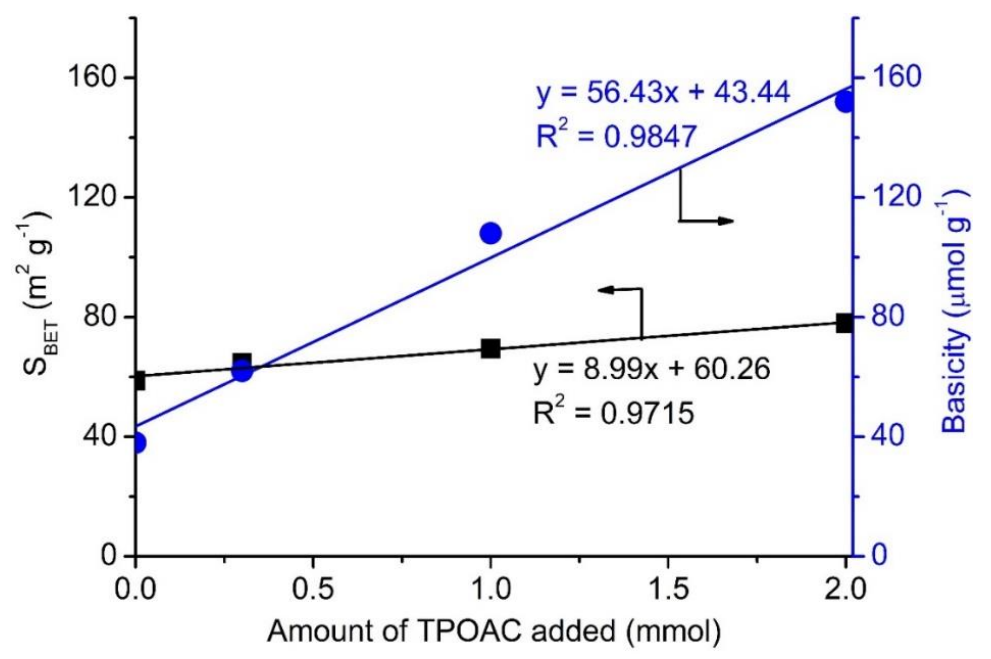

Figure 8. Correlation plots between the amount of TPOAC added with the specific surface area $\left(\mathrm{S}_{\mathrm{BET}}\right)$ and basicity of Cs-pollicite samples.

\subsection{Catalytic Reaction Study}

Solvent-free Claisen-Schmidt condensation of acetophenone and benzaldehyde was chosen as a model reaction to assess the catalytic behavior of hierarchical Cs-pollucite nanozeolites (Equation (1)). The influence of the catalytic reaction parameters, namely the reaction temperature, heating time, catalyst loading, molar ratio of acetophenone and benzaldehyde, and type of catalysts used, on the selective conversion to chalcone was systematically studied.<smiles>O=Cc1ccccc1</smiles>

Benzaldehyde<smiles>CC(=O)c1ccccc1</smiles>

Acetophenone<smiles>O=C(/C=C/c1ccccc1)c1ccccc1</smiles>

Chalcone 


\subsubsection{Effects of the Reaction Temperature and Time}

The catalytic activity of CP- $x(x=0,0.3,1.0$, and 2.0) in Claisen-Schmidt condensation of benzaldehyde and acetophenone was first studied at various heating temperatures (180, 190, and $\left.200{ }^{\circ} \mathrm{C}\right)$ under non-microwave instant heating conditions in a wide reaction time range (0-100 $\mathrm{min})$. Only chalcone was produced as a single reaction production in the entire catalytic reaction study. In the absence of catalyst, the conversion recorded at $200{ }^{\circ} \mathrm{C}$ after $100 \mathrm{~min}$ was low (30.1\%) (results not shown). In the presence of $\mathrm{CP}-x$ catalysts, the conversion increased significantly under the same reaction conditions (Figure $9 \mathrm{~A}(\mathrm{a})$ ). As seen, $\mathrm{CP}-2.0$ is the most reactive $(82.2 \%)$, followed by CP-1.0 $(78.2 \%)$, CP-0.3 (70.6\%), and CP-0 (68.5\%). Thus, the results demonstrate that Cs-pollucite nanocatalyst with more hierarchical porosities increased the accessible surface area, which is essential for the fast diffusion of reactant molecules and adsorption onto the basic sites before the molecules are converted to the reaction product (chalcone) [40].
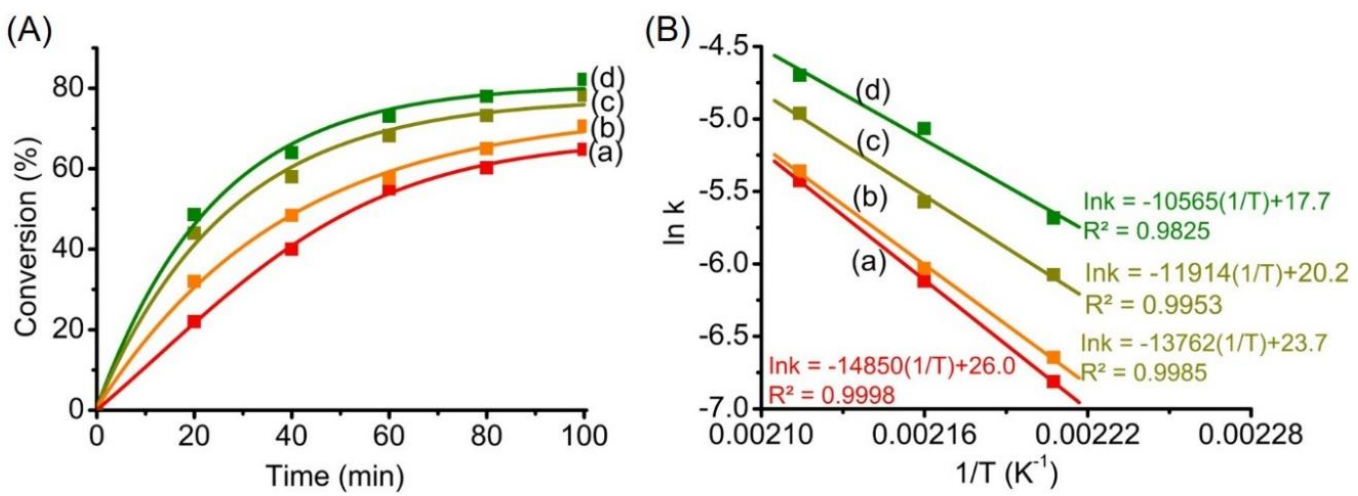

Figure 9. (A) Claisen-Schmidt condensation of benzaldehyde and acetophenone catalyzed with (a) CP-0, (b) CP-0.3, (c) CP-1.0, and (d) CP-2.0 nanocatalysts at $200{ }^{\circ} \mathrm{C}$, where the respective Arrhenius linear plots are also shown in (B) using the second-order rate constants determined at 180, 190, and $200{ }^{\circ} \mathrm{C}$.

The activation energies $\left(E_{a}\right)$ of catalyzed and non-catalyzed Claisen-Schmidt condensation reaction were calculated using the Arrhenius equation plot (Figure 9B), where the second-order rate constants, $\mathrm{k}_{2 \mathrm{nd}}$, were first determined based on the concentration of unreacted acetophenone at 180 , 190 , and $200{ }^{\circ} \mathrm{C}$ over various times (0-100 $\left.\mathrm{min}\right)$. The results indicate that the reaction catalyzed with CP-2.0 has the lowest $E_{a}$ value $\left(87.84 \mathrm{~kJ} \mathrm{~mol}^{-1}\right)$, followed by CP-1.0 (99.05 kJ mol $\left.{ }^{-1}\right), \mathrm{CP}-0.3(114.42$ $\left.\mathrm{kJ} \mathrm{mol}^{-1}\right), \mathrm{CP}-0\left(123.47 \mathrm{~kJ} \mathrm{~mol}^{-1}\right)$, and no catalyst $\left(184.97 \mathrm{~kJ} \mathrm{~mol}^{-1}\right)$. Thus, the catalytic kinetic study reveals that Claisen-Schmidt condensation of benzaldehyde and acetophenone is an activated reaction, where CP- $x$ nanocatalyst (particularly CP-2.0) offers an alternative and faster reaction route that has lower activation energy [41]. Hence, the optimum temperature and reaction time were chosen to be $200{ }^{\circ} \mathrm{C}$ and $100 \mathrm{~min}$ for further catalytic study where CP-2.0 was used as the catalyst.

\subsubsection{Effect of Catalyst Loading}

Catalyst loading plays an important role in the catalytic reaction [42], and hence, it was studied in the range $0-0.10 \mathrm{~g}$ using the following conditions: $200{ }^{\circ} \mathrm{C}, 40 \mathrm{~min}$, acetophenone:benzaldehyde molar ratio $=5 \mathrm{mmol}: 10 \mathrm{mmol}$. Only a $9.0 \%$ conversion was recorded when no catalyst was applied (Figure 10). The conversion, however, increased tremendously when CP-2.0 nanocatalyst was added. In general, the reaction conversion increased with the catalyst loading, where the highest reaction conversion ( $82.2 \%$ ) was achieved by using $0.50 \mathrm{~g}$ of CP-2.0 catalyst. A slight decrease in the reaction conversion $(77.9 \%)$, however, was recorded when $1.00 \mathrm{~g}$ of catalyst was used. This observation can be explained by the inhomogeneous mixing between reactants and catalyst as a result of the use of excessive catalyst that causes inefficient stirring. Hence, $0.50 \mathrm{~g}$ of CP-2.0 nanocatalyst was chosen for the further reaction study. 


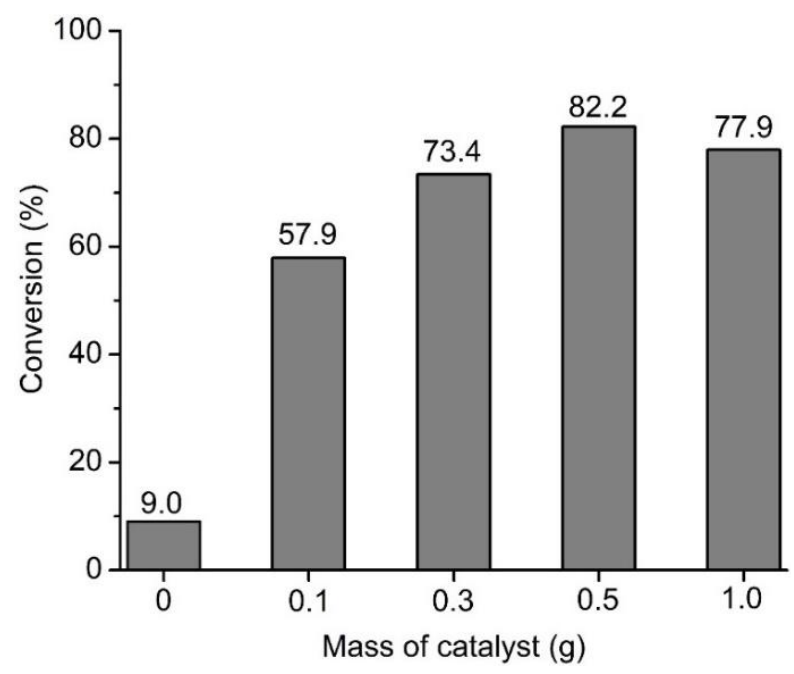

Figure 10. Effect of catalyst loading on the conversion of Claisen-Schmidt condensation of benzaldehyde and acetophenone. Catalyst $=\mathrm{CP}-2.0$, reaction temperature $=200{ }^{\circ} \mathrm{C}$, reaction time $=100 \mathrm{~min}$, benzaldehyde $=10 \mathrm{mmol}$, acetophenone $=5 \mathrm{mmol}$, solvent free.

\subsubsection{Effect of the Acetophenone to Benzaldehyde Molar Ratio}

The effect of the acetophenone to benzaldehyde molar ratio was investigated while the other reaction parameters were kept constant (Figure 11). In general, the reaction conversion was affected by changing the acetophenone to benzaldehyde molar ratio, where the conversion was enhanced by increasing the benzaldehyde concentration. The highest conversion $(82.2 \%)$ was recorded when the acetophenone to benzaldehyde molar ratio of 5:15 was used. Further increasing the benzaldehyde concentration, however, reduced the reaction conversion to $76.3 \%$. The Claisen-Schmidt condensation was also carried out using benzaldehyde as a limiting reagent instead of acetophenone. Interestingly, the reaction became less reactive, where low conversion (43.3-54.2\%) was recorded when the acetophenone to benzaldehyde molar ratio was changed to 10:5 and 20:5, respectively. Hence, the results show that acetophenone has to first be activated on the active sites prior to reaction with benzaldehyde.

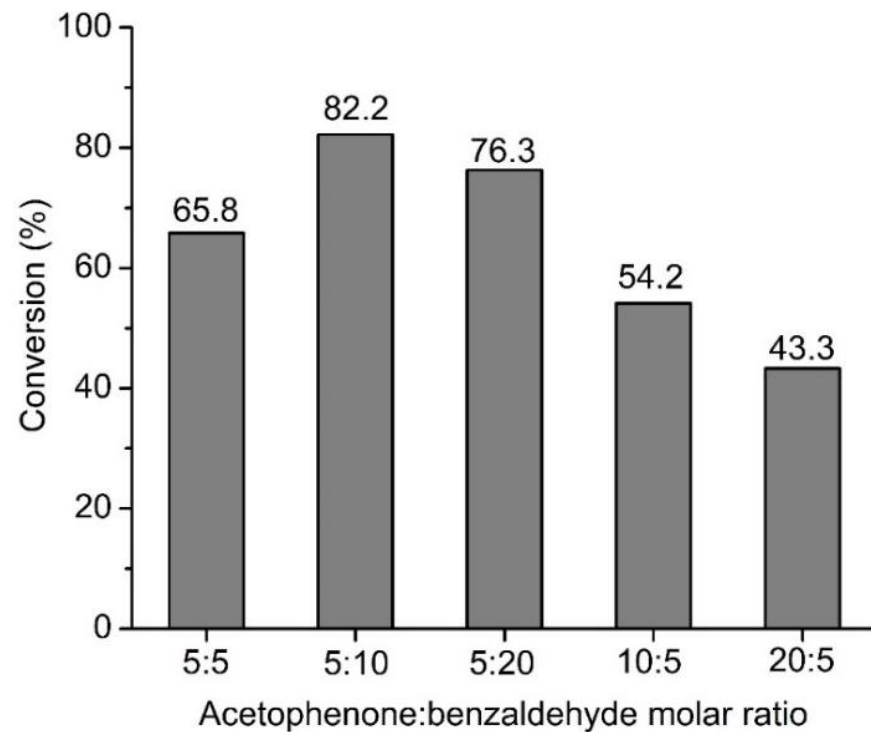

Figure 11. Effect of the acetophenone:benzaldehyde molar ratio on the conversion of Claisen-Schmidt condensation. Catalyst $=\mathrm{CP}-2.0$, catalyst loading $=0.50 \mathrm{~g}$, reaction temperature $=200{ }^{\circ} \mathrm{C}$, reaction time $=100 \mathrm{~min}$, solvent-free. 


\subsubsection{Catalyst Comparative Study}

The catalytic performance of CP-2.0 was also compared with common homogeneous and heterogeneous catalysts, such as $\mathrm{KOH}, \mathrm{Na}_{2} \mathrm{CO}_{3}, \mathrm{NaOH}, \mathrm{CsOH}$, and $\mathrm{NaX}$ zeolite, where an equimolar amount to CP-2.0 nanocatalyst was used; $1.984 \mathrm{mmol}$ is equivalent to $0.50 \mathrm{~g}$ of CP-2.0 (Figure 12A). As expected, $\mathrm{CsOH}$ - an extremely alkaline metal hydroxide-showed the highest reaction conversion (91.4\%) but the reaction was only $92 \%$ selective to chalcone due to the co-occurrence of a secondary Cannizzaro reaction of benzaldehyde to benzyl alcohol and benzoic acid, and slight product decomposition to non-identified compounds at the high temperature. Interestingly, no product decomposition was observed for the reactions catalyzed with other catalyst counterparts, where CP-2.0 displayed the second highest reaction conversion ( $82.2 \%$ conversion), followed by $\mathrm{KOH}(70.3 \%), \mathrm{NaOH}$ $(61.1 \%), \mathrm{NaX}$ zeolite $(53.7 \%)$, and $\mathrm{Na}_{2} \mathrm{CO}_{3}(48.8 \%)$. Although $\mathrm{CsOH}$ is the most reactive catalyst, it is less selective, hazardous, corrosive, and not reusable. In contrast, CP-2.0 is not corrosive. Hence, it can be easily handled and stored. Furthermore, CP-2.0 nanocatalyst has high catalyst reusability, where its crystallinity and catalytic reactivity were preserved even after five reaction runs (Figure 12B,C).
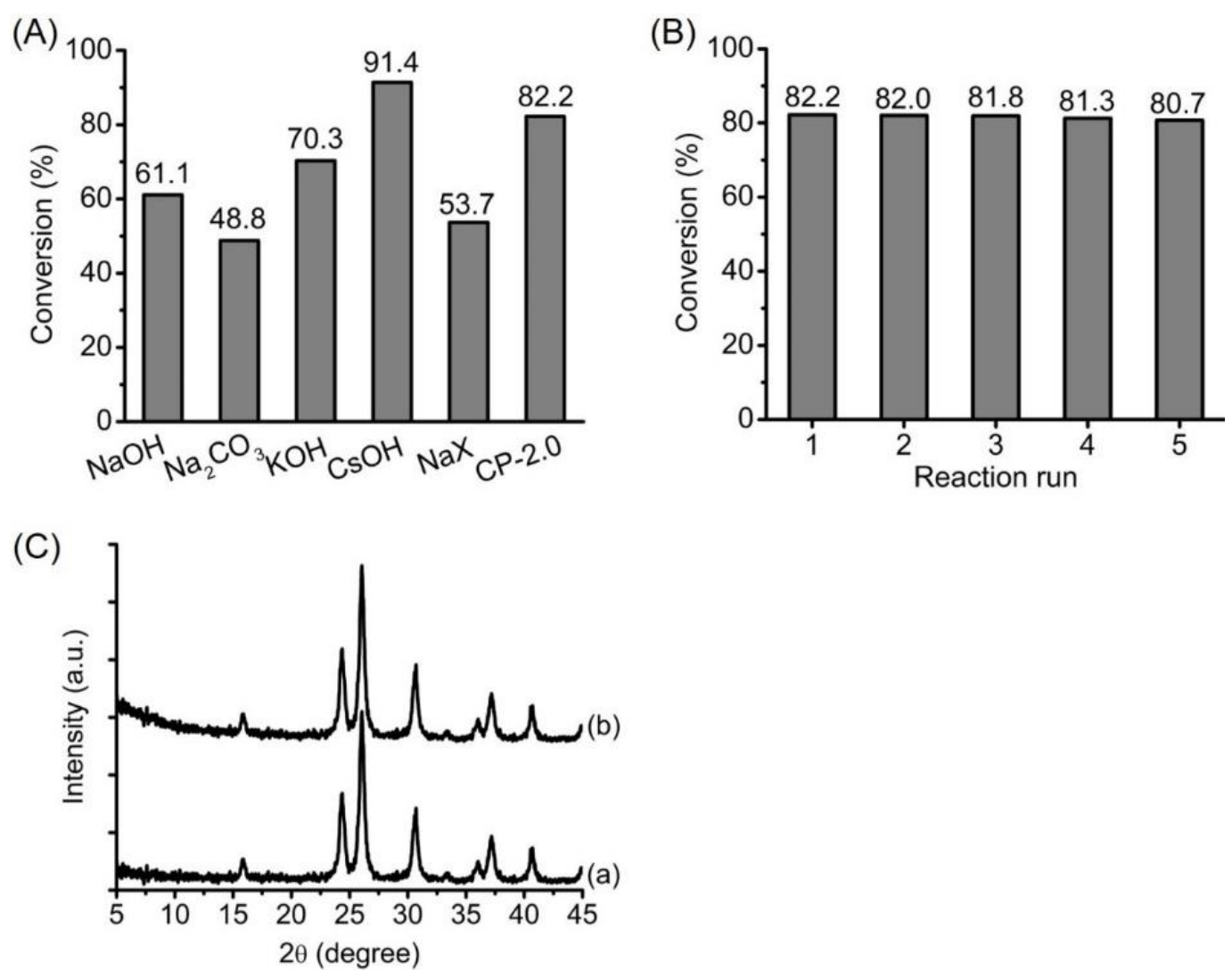

Figure 12. (A) Conversion of acetophenone in Claisen-Schmidt condensation reaction using different catalysts (reaction temperature $=200{ }^{\circ} \mathrm{C}$, time $=100 \mathrm{~min}$, benzaldehyde $=10 \mathrm{mmol}$, acetophenone $=5 \mathrm{mmol}),(\mathrm{B})$ catalyst reusability test of CP-2.0 in Claisen-Schmidt condensation of benzaldehyde and acetophenone, and (C) XRD patterns of (a) fresh CP-2.0 and (b) CP-2.0 after five consecutive reaction runs.

\section{Conclusions}

In conclusion, Cs-pollucite nanozeolite with hierachical micro/macroporosity was successfully synthesized under hydrothermal treatment with the aid of TPOAC porogen. The results show that TPOAC participates in the crystallization of Cs-pollucite, where the inclusion of TPOAC during the formation of $\mathrm{Cs}$-pollucite gives rise to a highly accessible surface area with micro/macropore sizes. Furthermore, the amount of TPOAC added during the synthesis of hierarchical Cs-pollucite has a 
proportional correlation to the accessible surface area and basicity of the solids obtained. Among the four Cs-pollucite samples prepared, CP-2.0 had the smallest crystallite size. It also exhibited the highest $\mathrm{S}_{\mathrm{BET}}$, accessible micro/macroporosity, and basicity (number of basic sites and basic strength). For the catalytic Claisen-Schmidt condensation of benzaldehyde and acetophenone, CP-2.0 was proven as an excellent and recyclable solid base catalyst. Hence, this hierarchical nanozeolite with accessible micro/macroporosity and high basicity has great potential in advanced applications, particularly in adsorption and catalytic technologies.

Author Contributions: A.G.M.S.: Performed most of the experiments, wrote the manuscript. F.K., T.-C.L. and E.-P.N.: Wrote and proof-read the manuscript, supervised A.G.M.S., give idea for the entire project, applied research funding. S.R. and T.J.D.: Run and interpreted $\mathrm{nmR}$ analysis, proofread the manuscript. All authors have read and agreed to the published version of the manuscript.

Funding: The financial support from FRGS (203/PKIMIA/6711642) grant is gratefully acknowledged. The doctoral scholarship from University of Hail, Saudi Arabia is also acknowledged.

Conflicts of Interest: The authors declare no conflict of interest.

\section{Abbreviations and Symbols}

The following abbreviations and symbols are used in this manuscript:

AlPO-11 Aluminophosphate number 11

AlPO-5 Aluminophosphate number 5

ca. Circa (approximately)

$\mathrm{CO}_{2}$-TPD Temperature-programmed desorption of carbon dioxide

DEC Decoupling

DFT Density Functional Theory

$\mathrm{E}_{\mathrm{a}} \quad$ Activation energy

FAU Faujasite

FESEM Field emission scanning electron microscopy

GC-FID Gas chromatography-flame ionization detector

GC-MS Gas chromatography-mass spectrometry

ICP-OES Inductively coupled plasma-optical emission spectroscopy

IR Infrared

LTA Linde Type A

MAS Magic angle spinning

NMR Nuclear magnetic nesonance

$\mathrm{P} / \mathrm{P}_{\mathrm{o}} \quad$ Partial pressure

PDADMA Polyallyldimethylammonium

$\mathrm{R}^{2} \quad$ R-squared

SAPO-5 Silicoaluminophosphate number 5

$\mathrm{S}_{\mathrm{BET}} \quad$ Specific surface area

$S_{\text {ext }} \quad$ External surface area

S micro Micropore surface area

TG Thermogravimetry

TMS Tetramethylsilane

TPHAC Dimethylheptadecyl[3-(trimethoxysilyl)propyl]ammonium chloride

TPOAC Dimethyloctadecyl[3-(trimethoxysilyl)propyl]ammonium chloride

$\mathrm{V}_{\text {micro }} \quad$ Micropore volume

$\mathrm{V}_{\text {total }} \quad$ Total pore volume

XRD X-ray diffraction

$\sigma \quad$ Pore size 


\section{References}

1. Davis, M.E. Ordered porous materials for emerging applications. Nature 2002, 417, 813-821. [CrossRef] [PubMed]

2. Rahimi, M.; Ng, E.-P.; Bakhtiari, K.; Vinciguerra, M.; Ahmad, H.A.; Awala, H.; Mintova, S.; Daghighi, M.; Rostami, F.B.; De Vries, M.; et al. Zeolite Nanoparticles for Selective Sorption of Plasma Proteins. Sci. Rep. 2015, 5, 17259. [CrossRef] [PubMed]

3. Ng, E.-P.; Nur, H.; Wong, K.-L.; Muhid, M.N.M.; Hamdan, H. Generation of Brönsted acidity in AlMCM-41 by sulphation for enhanced liquid phase tert-butylation of phenol. Appl. Catal. A Gen. 2007, 323, 58-65. [CrossRef]

4. Wong, S.-F.; Deekomwong, K.; Wittayakun, J.; Ling, T.C.; Muraza, O.; Adam, F.; Ng, E.-P. Crystal growth study of K-F nanozeolite and its catalytic behavior in Aldol condensation of benzaldehyde and heptanal enhanced by microwave heating. Mater. Chem. Phys. 2017, 196, 295-301. [CrossRef]

5. Mastinu, A.; Kumar, A.; Maccarinelli, G.; Bonini, S.A.; Premoli, M.; Aria, F.; Gianoncelli, A.; Memo, M. Zeolite Clinoptilolite: Therapeutic Virtues of an Ancient Mineral. Molecules 2019, 24, 1517. [CrossRef] [PubMed]

6. He, G.; Li, J.; Pang, X.; Wang, H.; Hua, J.; He, J.; Fang, S.-M.; Chang, Y.-X. A Beta/ZSM-22 Zeolites-Based-Mixed Matrix Solid-Phase Dispersion Method for the Simultaneous Extraction and Determination of Eight Compounds with Different Polarities in Viticis Fructus by High-Performance Liquid Chromatography. Molecules 2019, 24, 3423. [CrossRef]

7. De Klerk, A. Zeolites as Catalysts for Fuels Refining after Indirect Liquefaction Processes. Molecelus 2018, 23, 115. [CrossRef]

8. Kim, Y.-S.; Cho, K.-S.; Lee, Y.-K. Structure and Activity of $\mathrm{Ni}_{2} \mathrm{P} /$ Desilicated Zeolite $\beta$ Catalysts for Hydrocracking of Pyrolysis Fuel Oil into Benzene, Toluene, and Xylene. Catalysts 2020, 10, 47. [CrossRef]

9. Feng, R.; Chen, K.; Yan, X.; Hu, X.; Zhang, Y.; Wu, J. Synthesis of ZSM-5 Zeolite Using Coal Fly Ash as an Additive for the Methanol to Propylene (MTP) Reaction. Catalysts 2019, 9, 788. [CrossRef]

10. Hou, L.; Li, J.; Lu, Z. Hollow-structured pollucite microspheres and the formation mechanism. Microporous Mesoporous Mater. 2019, 282, 228-236. [CrossRef]

11. Brundu, A.; Cerri, G. Thermal transformation of Cs-clinoptilolite to CsAlSi ${ }_{5} \mathrm{O}_{12}$. Microporous Mesoporous Mater. 2015, 208, 44-49. [CrossRef]

12. IZA-SC. Database of Zeolite Structures. Available online: http://www.iza-structure.org/databases/ (accessed on 25 December 2019).

13. Wong, S.-F.; Deekamwong, K.; Wittayakun, J.; Ling, T.C.; Muraza, O.; Lee, H.L.; Adam, F.; Ng, E.-P. Nanocrystalline K-F Zeolite from Rice Husk Silica as an Eco-friendly Solid Base Catalyst for the Synthesis of Jasminaldehyde under Microwave Irradiation. Sains Malays. 2018, 47, 337-345.

14. Wong, S.-F.; Awala, H.; Vincente, A.; Retoux, R.; Ling, T.C.; Mintova, S.; Mukti, R.R.; Ng, E.-P. K-F zeolite nanocrystals synthesized from organic-template-free precursor mixture. Microporous Mesoporous Mater. 2017, 249, 105-110. [CrossRef]

15. Ghrear, T.M.A.; Rigolet, S.; Daou, T.J.; Mintova, S.; Ling, T.C.; Tan, S.H.; Ng, E.-P. Synthesis of Cs-ABW nanozeolite in organotemplate-free system. Microporous Mesoporous Mater. 2019, 277, 78-83. [CrossRef]

16. Ng, E.-P.; Wong, K.-L.; Ng, D.T.-L.; Awala, H.; Mukti, R.R.; Adam, F.; Mintova, S. AlPO-5 nanocrystals templated by 1-ethyl-2,3-dimethylimidazolium hydroxide and their textural and water sorption properties. Mater. Chem. Phys. 2017, 188, 49-57. [CrossRef]

17. Mohammad, S.A.G.; Ahmad, N.H.; Goldyn, K.; Mintova, S.; Ling, T.C.; Ng, E.-P. Nanosized Cs-pollucite zeolite synthesized under mild condition and its catalytic behaviour. Mater. Res. Exp. 2018, 6, 025026. [CrossRef]

18. Ng, E.-P.; Mohammad, S.A.G.; Rigolet, S.; Daou, T.J.; Mintova, S.; Ling, T.C. Micro- and macroscopic observations of the nucleation process and crystal growth of nanosized Cs-pollucite in an organotemplate-free hydrosol. New J. Chem. 2019, 43, 17433-17440. [CrossRef]

19. Feyen, M.; Weidenthaler, C.; Güttel, R.; Schlichte, K.; Holle, U.; Lu, A.H.; Schüth, F. High-temperature stable, iron-based core-shell catalysts for ammonia decomposition. Chemistry 2011, 17, 598-605. [CrossRef]

20. Zhang, Z.; Pinnavaia, T.J. Mesoporous gamma-alumina formed through the surfactant-mediated scaffolding of peptized pseudoboehmite nanoparticles. Langmuir 2010, 26, 10063-10067. [CrossRef] 
21. Courtois, J.; Byström, E.; Irgum, K. Novel monolithic materials using poly(ethylene glycol) as porogen for protein separation. Polymer 2006, 47, 2603-2611. [CrossRef]

22. Le Ray, A.-M.; Gautier, H.; Bouler, J.-M.; Weiss, P.; Merle, C. A new technological procedure using sucrose as porogen compound to manufacture porous biphasic calcium phosphate ceramics of appropriate micro- and macrostructure. Ceram. Int. 2010, 36, 93-101. [CrossRef]

23. Vaysse, M.; Khan, M.K.; Sundararajan, P. Carbon Nanotube Reinforced Porous Gels of Poly(methyl methacrylate) with Nonsolvents as Porogens. Langmuir 2009, 25, 7042-7049. [CrossRef] [PubMed]

24. Yuan, Y.; Tian, P.; Yang, M.; Fan, D.; Wang, L.; Xu, S.; Wang, C.; Wang, D.; Yang, Y.; Liu, Z. Synthesis of hierarchical beta zeolite by using a bifunctional cationicpolymer and the improved catalytic performance. RSC Adv. 2015, 5, 9852-9860. [CrossRef]

25. Fu, X.; Sheng, X.; Zhou, Y.; Fu, Z.; Zhao, S.; Bu, X.; Zhang, C. Design of micro-mesoporous zeolite catalysts for alkylation. RSC Adv. 2016, 6, 50630-50639. [CrossRef]

26. Cho, H.S.; Cho, K.; de Menorval, L.-C.; Ryoo, R. Generation of Mesoporosity in LTA Zeolites by Organosilane Surfactantfor Rapid Molecular Transport in Catalytic Application. Chem. Mater. 2009, 21, 5664-5673. [CrossRef]

27. Inayat, A.; Knoke, I.; Spiecker, E.; Schwieger, W. Assemblies of Mesoporous FAU-Type Zeolite Nanosheets. Angew. Chem. Int. Ed. 2012, 51, 1962-1965. [CrossRef]

28. Choi, M.; Srivastava, R.; Ryoo, R. Organosilane surfactant-directed synthesis of mesoporous aluminophosphates constructed with crystalline microporous frameworks. Chem. Commun. 2006, 42, 4380-4382. [CrossRef]

29. Diao, Z.; Cheng, L.; Hou, X.; Rong, D.; Lu, Y.; Yue, W.; Sun, D. Fabrication of the Hierarchical HZSM-5 Membrane with Tunable Mesoporosity for Catalytic Cracking of n-Dodecane. Catalysts 2019, 9, 155. [CrossRef]

30. Ng, E.-P.; Bahaman, N.; Mukti, R.R.; Ling, T.-C.; Ng, Y.H.; Adam, F. Detailed kinetic observation revealing the formation mechanism of chiral mesoporous silica (CMS) synthesized by cooperative self-assembly of anionic chiral surfactant. Mater. Res. Bull. 2015, 62, 192-199. [CrossRef]

31. Wang, C.; Yang, M.; Tian, P.; Xu, S.; Yang, Y.; Wang, D.; Yuan, Y.; Liu, Z. Dual template-directed synthesis of SAPO-34nanosheet assemblies with improved stability in themethanol to olefins reaction. J. Mater. Chem. A 2015, 3, 5608-5616. [CrossRef]

32. Zhang, M.; Xia, Z.; Liu, Q. Thermally stable $\mathrm{K}_{\mathrm{x}} \mathrm{Cs}_{1-\mathrm{x}} \mathrm{AlSi}_{2} \mathrm{O}_{6}: \mathrm{Eu}^{2+}$ phosphorsand their photoluminescence tuning. J. Mater. Chem. C 2017, 5, 7489-7494. [CrossRef]

33. Cheong, Y.-W.; Wong, K.-L.; Ling, T.C.; Ng, E.-P. Rapid synthesis of nanocrystalline zeolite W with hierarchical mesoporosity as an efficient solid basic catalyst for nitroaldol Henry reaction of vanillin with nitroethane. Mater. Express 2018, 8, 463-468. [CrossRef]

34. Ng, E.-P.; Goh, J.-Y.; Ling, T.C.; Mukti, R.R. Eco-friendly synthesis for MCM-41 nanoporous materials using the non-reacted reagents in mother liquor. Nanoscale Res. Lett. 2013, 8, 120. [CrossRef] [PubMed]

35. Ng, E.-P.; Awala, H.; Ghoy, J.-P.; Vicente, A.; Ling, T.C.; Ng, Y.H.; Mintova, S.; Adam, F. Effects of ultrasonic irradiation on crystallization and structural properties of EMT-type zeolite nanocrystals. Mater. Chem. Phys. 2015, 159, 38-45. [CrossRef]

36. Ng, E.-P.; Lim, G.K.; Khoo, G.-L.; Tan, K.-H.; Ooi, B.S.; Adam, F.; Ling, T.C.; Wong, K.-L. Synthesis of colloidal stable Linde Type J (LTJ) zeolite nanocrystals from rice husk silica and their catalytic performance in Knoevenagel reaction. Mater. Chem. Phys. 2015, 155, 30-35. [CrossRef]

37. Chen, Z.; Dong, L.; Chen, C.; Wang, Y.; Wang, Y.; Zhang, J.; Qian, W.; Hong, M. Direct synthesis of core-shell MFI zeolites with spatially tapered trimodal mesopores via controlled orthogonal self-assembly. Nanoscale 2019, 11, 16667-16676. [CrossRef]

38. Choo, M.-Y.; Juan, J.C.; Oi, L.E.; Ling, T.-C.; Ng, E.-P.; Noorsaadah, A.R.; Centi, G.; Lee, K.T.; Rahman, N.A. The role of nanosized zeolite $\mathrm{Y}$ in the $\mathrm{H}_{2}$-free catalytic deoxygenation of triolein. Catal. Sci. Technol. 2019, 9, 772-782. [CrossRef]

39. Ghrear, T.M.A.; Ng, E.-P.; Vaulot, C.; Daou, T.J.; Ling, T.C.; Tan, S.H.; Ooi, B.S.; Mintova, S. Recyclable synthesis of Cs-ABW zeolite nanocrystals from non-reacted mother liquors with excellent catalytic henry reaction performance. J. Environ. Chem. Eng. 2020, 8, 103579. [CrossRef]

40. Schneider, D.; Mehlhorn, D.; Zeigermann, P.; Kärger, J.; Valiullin, R. Transport properties of hierarchical micro-mesoporous materials. Chem. Soc. Rev. 2016, 45, 3439-3467. [CrossRef] 
41. Ben-Arfa, B.A.; Salvado, I.M.M.; Frade, J.R.; Pullar, R.C. Fast route for synthesis of stoichiometric hydroxyapatite by employing the Taguchi method. Mater. Des. 2016, 109, 547-555. [CrossRef]

42. Adam, F.; Appaturi, J.N.; Ng, E.-P. Halide aided synergistic ring opening mechanism of epoxides and their cycloaddition to $\mathrm{CO}_{2}$ using MCM-41-imidazolium bromide catalyst. J. Mol. Catal. A Chem. 2014, 386, 42-48. [CrossRef] 